\title{
PENGARUH NPF, NOM DAN FDR TERHADAP PEMBIAYAAN MURABAHAH DENGAN DPK SEBAGAI VARIABEL MODERATING
}

\author{
Rizki Farianti ${ }^{*}$, Bambang Agus Pramuka ${ }^{2}$, Atiek Sri Purwati ${ }^{3}$ \\ 1,2,3 Universitas Jenderal Soedirman \\ \riskifarianti@gmail.com,bpramuka@yahoo.com, aisyaatiek@gmail.com
}

\begin{abstract}
: This study aims to determine the Non Performing Financing (NPF), Net Operating Margin (NOM) and Financing to Deposit Ratio (FDR) on Murabahah Financing with Third Party Funds (TPF) as the Moderating Variable. The population in this study are Islamic Banks that publishes their financial statements to Otoritas Jasa Keuangan (OJK) and each website of Islamic Banks for the period 2013 to 2017, with a sampling technique that is purposive sampling, the samples taken were 8 Islamic Banks in Indonesia obtained were analyzed by moderating regression analysis technique. The results of this study indicate that: (1) Non Performing Financing (NPF) does not negatively affect murabahah financing at Islamic Banks; (2) Net Operating Margin (NOM) has a positive effect on murabahah financing at Islamic Banks; (3) Financing to Deposit Ratio (FDR) has a positive effect on murabahah financing at Islamic Banks; (4) Third Party Funds (DPK) do not moderate the negative influence of NPF on murabahah financing at Islamic Banks; (5) Third Party Funds (DPK) strengthen the positive influence of NOM on murabahah financing at Islamic Banks; (6) Third Party Funds (DPK) strengthen the positive influence of FDR on murabahah financing at Islamic Banks. The implication of this research is the result of this study can be used as an effort to increase murabahah financing. To increase the amount of murabahah financing, managerial in Islamic Banks in Indonesia need to prioritize policies related to Net Operating Margin (NOM), Financing to Deposit Ratio (FDR) and Third Party Funds (DPK).
\end{abstract}

Keywords $\quad$ : NPF, NOM, FDR, DPK, murabahah

\section{LATAR BELAKANG}

Kesadaran masyarakat muslim yang semakin meningkat akan riba dalam sistem bunga pada bank konvensional membuat lahirnya bank syariah. Kesadaran untuk menghindari riba inilah yang mendorong masyarakat muslim untuk mencari solusi pemenuhan kebutuhan mereka baik dalam investasi maupun pemenuhan modal. Lahirnya bank syariah menjadi lembaga yang membantu umat muslim untuk dapat tetap menggunakan jasa yang sama seperti yang ditawarkan oleh bank konvensional tetapi dengan tanpa unsur riba di dalamnya. Unsur riba dalam bank konvensional terdapat dalam sistem bunga yang merupakan suatu hal yang tidak dibenarkan dalam 
hukum islam. Hal ini menyebabkan bank syariah meninggalkan sistem bunga dan menggunakan sistem bagi hasil dalam kegiatan operasinya.

Menurut para ahli fiqih riba merupakan perbuatan batil yaitu ketidakadilan atau diam menerima ketidakadilan dalam hal pengambilan tambahan harta pokok atau modal baik dalam utang piutang maupun jual beli. Pelarangan riba dimaksudkan untuk menghapus ketidakadilan dan penegakan keadilan dalam perekonomian (Kalsum, 2014).

Industri keuangan syariah khususnya perbankan syariah di Indonesia mengalami perkembangan dari tahun ke tahun. Perkembangan ini berpotensi untuk menjadikan industri keuangan syariah menjadi lokomotif ekonomi nasional. Hingga akhir tahun 2017 tren yang positif mengenai perkembangan ekonomi syariah diperlihatkan melalui data dari Otoritas Jasa Keuangan (OJK), data tersebut menunjukan penyaluran biaya perbankan syariah meningkat hingga 15,75\% secara tahunan. Hal tersebut dapat dilihat dari peningkatan Dana Pihak Ketiga (DPK) hingga 20,54\%. Bahkan pada aset perbankan syariah menunjukan pertumbuhan yang cukup signifikan yakni mencapai 19,79\%. Angka tersebut lebih tinggi dibanding dengan tingkat pertumbuhan aset perbankan konvensional yang hanya mencapai 11,20\%.

Bank syariah menjalankan fungsinya sebagai penghimpun dana, penyalur dana dan penyedia jasa-jasa perbankan sesuai dengan prinsip dan hukum islam. Pada bank syariah proses penghimpunan dana dilakukan dengan akad titipan (wadi'ah) dan investasi (mudharabah), sedangkan untuk proses penyaluran dana bank syariah memiliki akad mudharabah, musyarakah, murabahah, istishna dan qardh. Dari produk dan layanan tersebut, yang berkaitan dengan aktivitas bisnis dari bank syariah adalah produk dan layanan dalam proses penyaluran dana atau sering disebut dengan pembiayaan. Pembiayaan yang paling diminati oleh nasabah bank syariah adalah pembiayaan dengan digunakannya akad murabahah. Pembiayaan murabahah ini mengambil porsi terbesar dalam semua jenis pembiayaan yang ditawarkan oleh perbankan syariah. Namun sayangnya, untuk rasio pembiayaan murabahah dibanding dengan seluruh pembiayaan yang dikeluarkan oleh bank, pembiayaan murabahah mengalami penurunan setiap tahunnya. Hal ini dapat dilihat pada tabel 1.1 dibawah ini:

Tabel 1 Komposisi Pembiayaan Mudharabah, Musyarakah dan Murabahah BUS dan UUS Tahun 2013-2017 (dalam miliar rupiah)

\begin{tabular}{lccccc}
\hline \multicolumn{1}{c}{ Akad } & $\mathbf{2 0 1 3}$ & $\mathbf{2 0 1 4}$ & $\mathbf{2 0 1 5}$ & $\mathbf{2 0 1 6}$ & $\mathbf{2 0 1 7}$ \\
\hline Mudharabah & 13.625 & 14.354 & 14.820 & 15.292 & 17.090 \\
Rasio & $7,40 \%$ & $7,20 \%$ & $6,96 \%$ & $6,16 \%$ & $5,98 \%$ \\
Musyarakah & 39.874 & 49.336 & 60.713 & 78.421 & 101.561 \\
Rasio & $21,66 \%$ & $24,78 \%$ & $28,50 \%$ & $31,62 \%$ & $35,54 \%$ \\
Murabahah & 110.565 & 117.371 & 122.111 & 139.536 & 150.276 \\
Rasio & $60,05 \%$ & $58,88 \%$ & $57,33 \%$ & $56,26 \%$ & $52,60 \%$ \\
\hline
\end{tabular}

Sumber: Otoritas Jasa Keuangan

Berdasarkan tabel 1.1 tentang komposisi pembiayaan mudharabah, musyarakah dan murabahah di atas dapat dilihat bahwa dari tahun 2013-2017 pembiayaan yang paling banyak disalurkan oleh perbankan syariah adalah pembiayaan murabahah hingga mencapai $60 \%$ dari total pembiayaan yang disalurkan oleh bank syariah. Namun dapat dilihat untuk pembiayaan murabahah setiap tahunnya mengalami penurunan dari $60 \%$ hingga hampir mencapai 50\%. Hal ini menunjukan bahwa dalam faktor internal terdapat penurunan kemampuan bank syariah untuk dapat menyediakan layanan pembiayaan murabahah kepada masyarakat. Perbankan syariah 
harus dapat memperbaiki dan meningkatkan pembiayaan murabahah melalui analisa lebih lanjut terhadap faktor-faktor yang mempengaruhi besarnya pembiayaan murabahah yang dapat disalurkan agar risiko yang akan terjadi dapat dihindari dan diminimalkan. Hal ini akan membuat pemintaan pasar akan layanan pembiayaan dengan akad murabahah dapat diberikan oleh perbankan syariah dengan maksimal. Faktor yang diduga dapat mempengaruhi besarnya pembiayaan murabahah yang disalurkan oleh perbankan syariah adalah Non Performing Financing (NPF), Net operating margin (NOM), dan Financing to Deposit Ratio (FDR).

Pada penelitian terdahulu terdapat hasil yang kontradiktif mengenai faktor yang mempengaruhi besarnya pembiayaan murabahah yang disalurkan. Berdasarkan penelitian yang dilakukan Nahrawi (2017) menjelaskan bahwa NPF berpengaruh negatif dan signifikan terhadap pembiayaan murabahah, namun dalam penelitian Gumilarty dan Indriani (2017) menjelaskan bahwa NPF berpengaruh positif. Sedangkan untuk variabel Financing to Deposit Ratio (FDR), pada penelitian Prastanto (2013) menjelaskan bahwa FDR berpengaruh positif terhadap pembiayaan murabahah, namun dalam penelitian yang dilakukan Asnaini dan Erawati (2017) menjelaskan bahwa FDR berpengaruh negatif namun tidak berpengaruh secara signifikan terhadap pembiayaan murabahah.

Adanya perbedaan hasil penelitian tersebut memungkinkan adanya variabel lain yang menginteraksi hubungan antara variabel independen dengan variabel dependen dari penelitian sebelumnya. Variabel tersebut disebut variabel moderasi yang merupakan suatu variabel independen lain yang dimasukkan ke dalam model karena mempunyai efek kontingensi dari hubungan variabel dependen dan variabel independen sebelumnya (Hartono, 2017).

Dana Pihak Ketiga (DPK) diduga dapat memoderasi hubungan Non Performing Financing (NPF), Net Operating Margin (NOM) dan Financing to Deposit Ratio (FDR) terhadap pembiayaan murabahah. Penelitian ini menggunakan variabel moderasi Dana Pihak Ketiga (DPK) karena penelitian ini menggunakan teori Stewardship. Berdasarkan teori tersebut steward akan termotivasi untuk bertindak sesuai keinginan principal. Adanya rasa kepercayaan bahwa steward akan bertindak sesuai keinginan principal maka principal akan menaruh kepercayaan dengan menghimpun dananya di bank syariah. Dana yang dihimpun dari nasabah itu lah yang disebut dengan Dana Pihak Ketiga (DPK).

Dana Pihak Ketiga (DPK) memiliki kemungkinan dapat memoderasi hubungan $N P F, N O M$ dan FDR terhadap pembiayaan murabahah. Artinya besarnya NPF, NOM dan $F D R$ tidak berpengaruh langsung terhadap besarnya pembiayaan murabahah yang dapat disalurkan oleh bank syariah melainkan bergantung pada seberapa besar Dana Pihak Ketiga (DPK) yang dapat dihimpun oleh bank syariah.

Penelitian ini merupakan pengembangan dari penelitian Nahrawi (2017) namun dengan model yang berbeda yaitu digunakannya variabel moderasi, selain itu perbedaan penelitian ini terletak pada objek penelitian yakni menggunakan Bank Umum Syariah di Indonesia pada tahun 2013-2017, sedangkan pada penelitian Nahrawi (2017) menggunakan periode 2011-2015. Penelitian ini juga menambahkan variabel Net operating margin (NOM) sebagai variabel independen yang sebelumnya belum pernah diteliti pengaruhnya terhadap pembiayaan murabahah. 


\section{TEORI DAN METODE}

\subsection{Non Performing Financing (NPF)}

Non Performing Financing (NPF) adalah pembiayaan-pembiayaan yang kategori kolektabilitasnya masuk dalam kriteria pembiayaan kurang lancar, pembiayaan diragukan dan pembiayaan macet (Dendawijaya, 2005: 68). Penilaian NPF dapat diukur berdasarkan ketentuan peringkat yang ada pada Surat Edaran Bank Indonesia No. 9/24/DPbS perihal Sistem Penilaian Tingkat Kesehatan Bank Umum Berdasarkan Prinsip Syariah:

Tabel 2 Kriteria Penilaian Peringkat Non Performing Financing

\begin{tabular}{ccc}
\hline Peringkat & Keterangan & Kriteria \\
\hline 1 & Sangat Baik & $N P F<2 \%$ \\
2 & Baik & $2 \% \leq N P F<5 \%$ \\
3 & Cukup Baik & $5 \% \leq N P F<8 \%$ \\
4 & Kurang Baik & $8 \% \leq N P F<12 \%$ \\
5 & Tidak Baik & $N P F \geq 12 \%$ \\
\hline
\end{tabular}

Sumber: SE BI No. 9/24/DDPbs tanggal 30 Oktober 2007

\subsection{Net Operating Margin (NOM)}

Net Operating Margin (NOM) merupakan rasio untuk menggambarkan pendapatan operasional bersih sehingga diketahui kemampuan rata-rata aktiva produktif dalam menghasilkan laba (Rivai dan Arifin, 2010). Penilaian NOM dapat diukur berdasarkan ketentuan peringkat yang ada pada Surat Edaran Bank Indonesia No. 9/24/DDPbs tentang Sistem Penilaian Tingkat Kesehatan Bank Umum Berdasarkan Prinsip Syariah:

Tabel 3 Kriteria Penilaian Peringkat Net Operating Margin

\begin{tabular}{ccc}
\hline Peringkat & Keterangan & Kriteria \\
\hline 1 & Sangat Tinggi & $N O M>3 \%$ \\
2 & Tinggi & $2 \%<N O M \leq 3 \%$ \\
3 & Cukup Tinggi & $1,5 \%<N O M \leq 2 \%$ \\
4 & Rendah & $1 \%<N O M \leq 1,5 \%$ \\
5 & Sangat Rendah & $N O M \leq 1 \%$ \\
\hline
\end{tabular}

Sumber: SE BI No. 9/24/DDPbs tanggal 30 Oktober 2007

\subsection{Financing to Deposit Ratio (FDR)}

Financing to Deposit Ratio (FDR) merupakan rasio kinerja bank yang menunjukkan seberapa jauh kemampuan bank menyalurkan dana pinjaman yang berasal dari dana pihak ketiga bank tersebut (Muhammad, 2005:55). Menurut Dendawijaya (2005: 114) batas maksimum untuk Financing to Deposit Ratio (FDR) adalah sebesar $110 \%$ dimana apabila melebihi batas tersebut berarti likuiditas bank sudah termasuk kategori buruk, sebagai praktisi perbankan menyepakati batas aman dari Financing to Deposit Ratio (FDR) adalah sebesar 80\% dengan batas toleransi antara 85\%-100\%. Jika ratio FDR dibawah 80\% maka bank dinilai tidak melaksanakan fungsi intermediasi dengan baik, karena bank hanya menyalurkan dana yang dihimpun dibawah $80 \%$. 


\subsection{Dana Pihak Ketiga (DPK)}

Dana Pihak Ketiga (DPK) merupakan dana yang bersumber dari masyarakat, sumber dana terbesar yang paling diandalkan oleh bank. Bank dapat memanfaatkan dana tersebut agar menjadi pendapatan, yaitu dengan menyalurkan dana. Bank dapat menyalurkan dananya kepada masyarakat dalam bentuk pembiayaan. Semakin besar pendapatan yang dihasilkan oleh bank, berarti semakin besar pula kesempatan bank dalam menghasilkan keuntungan sehingga bank akan semakin tertarik dalam meningkatkan jumlah penyaluran dana kepada masyarakat (Dendawijaya, 2009).

\subsection{Pembiayaan Murabahah}

Murabahah adalah jaul beli barang pada harga asal dengan tambahan keuntungan yang disepakati antara pihak bank dan nasabah. Dalam murabahah, penjual menyebutkan harga pembelian barang kepada pembeli, kemudian ia mensyaratkan atas laba dalam jumlah tertentu. Pada perjanjian murabahah, bank membiayai pembelian barang yang dibutuhkan oleh nasabahnya dengan membeli barang itu dari pemasok, dan kemudian menjualnya kembali kepada nasabah dengan harga yang ditambah keuntungan atau di-mark-up. Dengan kata lain, penjualan barang kepada nasabah dilakukan atas dasar cost-plus profit (Sudarsono, 2008).

\subsection{Kerangka Pikir dan Pengembangan Hipotesis}

\section{a. Pengaruh NPF terhadap Pembiayaan Murabahah pada Bank Umum Syariah}

Semakin tinggi rasio ini maka akan semakin buruk kualitas kredit bank yang menyebabkan jumlah kredit bermasalah semakin besar, maka kemungkinan suatu bank dalam kondisi bermasalah semakin besar. Sehingga kemampuan bank untuk menyalurkan pembiayaan juga semakin rendah.

Penelitian yang memperkuat teori ini adalah penelitian yang dilakukan oleh Prastanto (2013) dan Asnaini \& Erawati (2017) yang menyatakan bahwa $N P F$ berpengaruh negatif terhadap pembiayaan Murabahah. Hal ini dapat dikatakan bahwa semakin tinggi $N P F$ maka semakin rendah pula pembiayaan Murabahah yang disalurkan oleh bank.

Berdasarkan uraian di atas, maka dapat dibangun hipotesis sebagai berikut:

$H_{1}$ : NPF berpengaruh negatif terhadap pembiayaan murabahah pada bank umum syariah.

\section{b. Pengaruh NOM terhadap Pembiayaan Murabahah pada Bank Umum Syariah}

Apabila suatu bank memiliki rasio NOM yang tinggi itu mengindikasi bahwa bank tersebut dapat menghasilkan margin murabahah yang tinggi sehingga profitabilitas yang didapatkan juga akan semakin tinggi. Itu akan berdampak pada volume pembiayaan murabahah, apabila profitabilitas semakin tinggi maka volume pembiayaan murabahah yang dapat disalurkan oleh bank juga semakin tinggi.

Penelitian yang memperkuat teori ini adalah penelitian yang dilakukan oleh Sari dan Haryanto (2017) yang menyatakan bahwa NOM berpengaruh positif terhadap Profitabilitas (ROA). Selain itu juga diperkuat pada penelitian 
Nahrawi (2017) yang menyatakan bahwa ROA berpengaruh positif terhadap pembiayaan murabahah. Hal ini dapat dikatakan bahwa semakin tinggi NOM maka semakin tinggi pula pembiayaan Murabahah yang disalurkan oleh bank. Berdasarkan uraian di atas, maka dapat dibangun hipotesis sebagai berikut:

$\mathrm{H}_{2}$ : NOM berpengaruh positif terhadap pembiayaan murabahah pada bank umum syariah.

\section{c. Pengaruh FDR terhadap Pembiayaan Murabahah pada Bank Umum Syariah}

Rasio ini merupakan rasio kinerja bank yang menunjukkan seberapa jauh kemampuan bank menyalurkan dana pinjaman yang berasal dari dana pihak ketiga bank tersebut (Muhammad, 2005:55). Semakin tinggi nilai FDR menunjukan semakin besar pembiayaan yang telah disalurkan ke nasabah. Apabila FDR semakin tinggi maka kesempatan bank untuk memperoleh keuntungan juga semakin tinggi sehingga bank akan lebih tertarik untuk menyalurkan pembiayaan di tahun berikutnya.

Penelitian yang memperkuat teori ini adalah penelitian yang dilakukan oleh Prastanto (2013) yang menyatakan bahwa FDR berpengaruh positif terhadap pembiayaan Murabahah. Hal ini dapat dikatakan bahwa semakin tinggi FDR maka semakin tinggi pula pembiayaan Murabahah yang disalurkan oleh bank.

Berdasarkan uraian di atas, maka dapat dibangun hipotesis sebagai berikut:

$H_{3}$ : FDR berpengaruh positif terhadap pembiayaan murabahah pada bank umum syariah.

\section{d. Pengaruh DPK terhadap hubungan antara NPF dengan Pembiayaan} Murabahah pada Bank Umum Syariah

Menurut Dendawijaya (2009), implikasi bagi bank akibat dari timbulnya kredit bermasalah adalah hilangnya kesempatan untuk memperoleh income dari kredit yang diberikan, sehingga dapat mengurangi perolehan laba. Apabila kesempatan memperoleh laba buruk maka bank akan berpikir ulang untuk meningkatkan jumlah pembiayaan murabahah, karena DPK yang digunakan untuk menyalurkan pembiayaan murabahah tersebut belum kembali.

Namun hal itu akan berbeda jika DPK yang dapat dihimpun oleh bank itu tinggi, maka bank akan meningkatkan penyaluran pembiayaan murabahah di tahun berikutnya karena kesempatan untuk memperoleh pendapatan juga semakin tinggi. Karena DPK merupakan sumber dana yang diandalkan untuk menghasilkan pendapatan dari penyaluran dana berupa pembiayaan (Dendawijaya, 2009:24).

Penelitian terdahulu seperti pada penelitian yang dilakukan Nahrawi (2017) menjelaskan bahwa $N P F$ berpengaruh negatif dan signifikan terhadap pembiayaan murabahah, namun hasil yang berbeda diperoleh dari penelitian Gumilaty dan Indriani (2016) yang menjelaskan bahwa NPF berpengaruh positif.

Perbedaan hasil ini lah yang menyebabkan penelitian ini menggunakan variabel moderasi berupa Dana Pihak Ketiga (DPK) yang memungkinkan menginteraksi hubungan NPF dengan pembiayaan murabahah. Adanya 
variabel moderasi Dana Pihak Ketiga (DPK) artinya jika DPK tinggi maka NPF yang tinggi sekalipun akan tetap meningkatkan pembiayaan murabahah. Hal ini dikarenakan bank akan tetap dapat menyalurkan pembiayaan murabahah selama DPK mereka cukup. Maka dari itu pengaruh negatif atas NPF terhadap pembiayaan murabahah akan lemah.

Berdasarkan uraian di atas, maka dapat dibangun hipotesis sebagai berikut:

$\mathrm{H}_{4}$ : DPK memperlemah pengaruh negatif NPF terhadap pembiayaan murabahah pada bank umum syariah.

e. Pengaruh DPK terhadap hubungan antara NOM dengan Pembiayaan Murabahah pada Bank Umum Syariah

Menurut Dendawijaya (2009), bank akan semakin tertarik dalam meningkatkan jumlah penyaluran dana kepada masyarakat, apabila bank memiliki kesempatan besar untuk menghasilkan keuntungan dari pendapatan yang mereka peroleh. Pendapatan dari Dana Pihak Ketiga (DPK) ini lah yang disebut dengan Net Operating Margin (NOM) yaitu pendapatan operational dari rata-rata aktiva produktifnya (Rivai dan Arifin, 2010).

Bank syariah akan mengalami kenaikan kemampuan dalam penyaluran pembiayaan murabahah apabila kesempatan mendapatkan keuntungan itu besar dan Dana Pihak Ketiga (DPK) yang berhasil dihimpun oleh bank itu tinggi. Hal ini dikarenakan Dana Pihak Ketiga (DPK) berpengaruh positif terhadap pembiayaan murabahah (Azka et.al, 2018).

Namun, berbeda jika Dana Pihak Ketiga (DPK) menginteraksi hubungan antara NOM dengan pembiayaan murabahah. Setinggi apapun NOM yang dimiliki bank syariah, tidak akan meningkatkan pembiayaan murabahah jika Dana Pihak Ketiga (DPK) yang dapat dihimpun oleh bank syariah itu rendah. Maka dari itu jika DPK tinggi maka DPK akan memperkuat pengaruh positif NOM terhadap pembiayaan murabahah, karena dengan DPK yang tinggi maka kesempatan untuk memperoleh keuntungan dari pendapatan akan naik sehingga bank akan meningkatkan pembiayaan.

Berdasarkan uraian di atas, maka dapat dibangun hipotesis sebagai berikut: $H_{5}$ : DPK memperkuat pengaruh positif NOM terhadap peningkatan pembiayaan murabahah pada bank umum syariah.

\section{f. Pengaruh DPK terhadap hubungan antara FDR dengan Pembiayaan Murabahah pada Bank Umum Syariah}

Menurut Dendawijaya (2009), bank akan semakin tertarik dalam meningkatkan jumlah penyaluran dana kepada masyarakat, apabila bank memiliki kesempatan besar untuk menghasilkan keuntungan dari pendapatan yang mereka peroleh. Sumber penyaluran dana yang paling diandalkan adalah dari Dana Pihak Ketiga (DPK). FDR yang tinggi akan meningkatkan pembiayaan murabahah yang dapat disalurkan oleh bank (Prastanto, 2013).

Namun hal itu akan berbeda jika bank tidak dapat menghimpun Dana Pihak Ketiga (DPK) dengan maksimal. Walaupun FDR pada tahun sebelumnya tinggi tetapi DPK yang dapat dihimpun oleh bank juga rendah, maka hal tersebut akan melemahkan pembiayaan murabahah yang dapat disalurkan oleh bank syariah pada tahun berikutnya.

Pada penelitian Prastanto (2013) menjelaskan bahwa FDR berpengaruh positif terhadap pembiayaan murabahah, namun dalam penelitian yang dilakukan Asnaini dan Erawati (2017) menjelaskan bahwa FDR berpengaruh 
negatif namun tidak berpengaruh secara signifikan terhadap pembiayaan murabahah.

Hasil yang tidak konsisten ini memungkinkan adanya variabel lain yang menginteraksi yaitu variabel moderasi. Dalam penelitian ini menggunakan Dana Pihak Ketiga (DPK) sebagai variabel moderasi. Adanya variabel moderasi Dana Pihak Ketiga (DPK) artinya FDR setinggi apapun pada tahun sebelumnya tidak akan meningkatkan pembiayaan murabahah di tahun berikutnya jika Dana Pihak Ketiga (DPK) yang dapat dihimpun oleh bank syariah itu rendah. Hal ini mengakibatkan jika DPK tinggi maka DPK akan memperkuat pengaruh positif FDR terhadap pembiayaan murabahah, dengan DPK yang tinggi maka kemampuan untuk menyalurkan pembiayaan juga tinggi karena bank memiliki dana untuk disalurkan kepada masyarakat.

Berdasarkan uraian di atas, maka dapat dibangun hipotesis sebagai berikut: $H_{6}:$ DPK memperkuat pengaruh positif FDR terhadap pembiayaan murabahah pada bank umum syariah

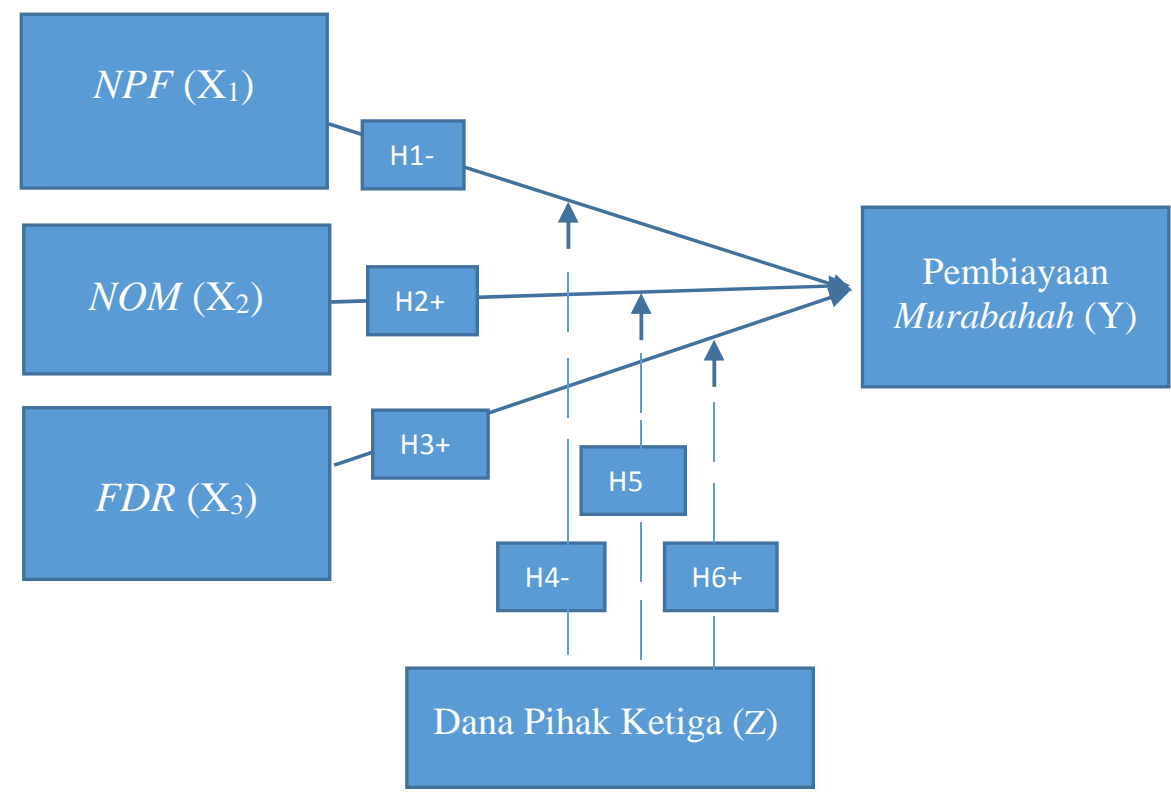

Gambar 1: Model Penelitian

\subsection{Metode Penelitian}

Penelitian ini memiliki populasi seluruh Bank Umum Syariah yang terdaftar di Otoritas Jasa Keuangan yang berjumlah 13 Bank Umum Syariah. Pemilihan sampel dalam penelitian ini menggunakan metode purposive sampling, dimana dalam penentuan sampel menggunakan kriteria yang telah ditetapkan sesuai dengan tujuan penelitian. Berdasarkan teknik tersebut diperoleh 8 bank umum syariah yang dijadikan sampel penelitian. Penelitian ini merupakan timelag sehingga untuk periode 2013-2017 terdapat 4 tahun periode penelitian, dimana untuk variabel independen menggunakan tahun 2013-2016 dan variabel dependen menggunakan tahun 2014-2017. Observasi dalam penelitian ini adalah 8 bank umum syariah selama kurun waktu 4 tahun dengan menggunakan laporan triwulan, sehingga diperoleh jumlah observasi sebanyak 128. Berikut ini adalah daftar sampel bank umum syariah yang digunakan: 
Tabel 4 Daftar BUS yang dijadikan Sampel Penelitian

\begin{tabular}{cl}
\hline No & \multicolumn{1}{c}{ Nama Bank } \\
\hline 1 & PT. Bank BCA Syariah \\
2 & PT. Bank BNI Syariah \\
3 & PT. Bank BRI Syariah \\
4 & PT. Bank Syariah Bukopin \\
5 & PT. Bank Syariah Mandiri \\
6 & PT. Bank Muamalat Indonesia \\
7 & PT. Bank Panin Dubai \\
8 & PT. Bank Mega Syariah \\
Sumber: data sekunder yang diolah
\end{tabular}

\section{HASIL DAN PEMBAHASAN}

\subsection{Hasil Analisis Data}

Teknik analisis data yang digunakan dalam penelitian ini adalah analisis regresi moderasi untuk mengetahui pengaruh $N P F$, NOM, dan FDR terhadap pembiayaan murabahah baik secara langsung maupun tidak langsung melalui DPK. Sebelum melakukan uji hipotesis terlebih dahulu dilakukan uji asumsi klasik yang terdiri dari uji normalitas, uji multikolinearitas, uji heteroskedastisitas dan uji autokorelasi.

\section{Analisis Statistik Deskriptif}

Tabel 5 Hasil Analisis Statistik Deskriptif

\begin{tabular}{lrrrrr}
\hline \multicolumn{1}{c}{$\begin{array}{l}\text { Variabel } \\
\text { Penelitian }\end{array}$} & $\mathrm{N}$ & \multicolumn{1}{c}{ Minimum } & \multicolumn{1}{c}{ Maximum } & \multicolumn{1}{c}{ Mean } & Std. Deviation \\
\hline NPF & 128 & 0,0100 & 7,2300 & 3,1459 & 1,8905 \\
NOM & 128 & 0,6800 & 17,1400 & 6,6917 & 3,6368 \\
FDR & 128 & 79,19 & 106,50 & 92,81 & 6,27 \\
DPK & 128 & 989067,00 & 60495574,00 & 16334127,86 & 17487363,97 \\
Pembiayaan & 128 & 400051,00 & 36010425,00 & 10791102,61 & 10957489,33 \\
\multicolumn{2}{l}{ Murabahah }
\end{tabular}

\section{Uji Asumsi Klasik}

Berdasarkan output uji normalitas data dapat diketahui bahwa nilai asymp. sig. (2-tailed) dari uji Kolmogorov-Smirnov Z untuk standardized residual variable adalah 0,322 lebih besar dari nilai $\alpha(0,05)$, sehingga dapat disimpulkan bahwa data yang digunakan berdistribusi normal. Adapun ringkasan hasil uji normalitas dapat dilihat pada Tabel 6.

Tabel 6 Ringkasan Hasil Uji Normalitas Data

\begin{tabular}{cccc}
\hline Variabel & $\begin{array}{c}\text { Kolmogorov } \\
\text { Smirnov }\end{array}$ & $\begin{array}{c}\text { Asymp. } \\
\text { Sig. }\end{array}$ & Keterangan \\
\hline Standardized Residual & 0,955 & 0,322 & $\begin{array}{c}\text { Distribusi } \\
\text { Normal }\end{array}$ \\
\hline
\end{tabular}

Sumber: data hasil spss

Berdasarkan output uji asumsi klasik dapat diketahui bahwa nilai VIF dari variabel Non Performing Financing ( $\left.\mathrm{X}_{1}\right)$, Net Operating Margin $\left(\mathrm{X}_{2}\right)$, variabel Financing to Deposit Ratio ( $\left.\mathrm{X}_{3}\right)$, Dana Pihak Ketiga (Z), variabel moderasi_1, moderasi_2 maupun nilai VIF variabel moderasi_3 masing-masing lebih kecil dari 10 sehingga dapat 
disimpulkan tidak terjadi multikolinearitas dalam model regresi. Ringkasan hasil uji multikolinearitas dapat dilihat pada Tabel 7.

Tabel 7 Ringkasan Hasil Uji Multikolinearitas

\begin{tabular}{|c|c|c|}
\hline Variabel Bebas & Nilai VIF & Keterangan \\
\hline Non Performing Financing & 1,330 & Tidak Ada Mulikolinieritas \\
\hline Net Operating Margin & 1,589 & Tidak Ada Mulikolinieritas \\
\hline $\begin{array}{l}\text { Financing to De } \\
\text { posit Ratio }\end{array}$ & 1,377 & Tidak Ada Mulikolinieritas \\
\hline Dana Pihak Ketiga & 1,622 & Tidak Ada Mulikolinieritas \\
\hline Moderasi_1 & 1,665 & Tidak Ada Mulikolinieritas \\
\hline Moderasi_2 & 1,937 & Tidak Ada Mulikolinieritas \\
\hline Moderasi_3 & 1,893 & Tidak Ada Mulikolinieritas \\
\hline
\end{tabular}

Sumber: data hasil spss

Mengacu pada hasil uji heteroskedastisitas menggunakan uji Glejser diketahui bahwa nilai signifikansi uji t variabel Non Performing Financing $\left(\mathrm{X}_{1}\right)$, Net Operating Margin ( $\left.\mathrm{X}_{2}\right)$, variabel Financing to Deposit Ratio ( $\left.\mathrm{X}_{3}\right)$, Dana Pihak Ketiga (Z), variabel moderasi_1, moderasi_2 maupun nilai signifikansi uji t dari variabel moderasi_3 masing-masing lebih besar dari $\alpha(0,05)$. Maka dapat disimpulkan bahwa tidak terdapat heteroskedastisitas dalam model regresi. Ringkasan uji hetroskedastisitas dapat dilihat pada Tabel 8.

Tabel 8 Ringkasan Hasil Uji Heteroskedastisitis

\begin{tabular}{lcc}
\hline \multicolumn{1}{c}{ Variabel Bebas } & Sig. & \multicolumn{1}{c}{ Keterangan } \\
\hline Non Performing Financing & 0,864 & Tidak Ada Heteroskedastisitas \\
Net Operating Margin & 0,147 & Tidak Ada Heteroskedastisitas \\
Financing to Deposit Ratio & 0,280 & Tidak Ada Heteroskedastisitas \\
Dana Pihak Ketiga & 0,336 & Tidak Ada Heteroskedastisitas \\
Moderasi_1 & 0,305 & Tidak Ada Heteroskedastisitas \\
Moderasi_2 & 0,117 & Tidak Ada Heteroskedastisitas \\
Moderasi_3 & 0,433 & Tidak Ada Heteroskedastisitas \\
\hline
\end{tabular}

Sumber: data hasil spss

Berdasarkan hasil uji autokorelasi dapat diketahui bahwa nilai Durbin-Watson (DW) hitung sebesar 2,025. Nilai tersebut dibandingkan dengan nilai Durbin Watson tabel untuk $\mathrm{n}=126$ dan jumlah variabel $(\mathrm{k})=8$, maka dapat ditentukan nilai $\mathrm{d}_{\mathrm{U}}=1,846$ dan $d_{L}=1,578$. Dengan demikian, maka nilai Durbin Watson hitung berada di antara nilai $d_{U}(1,846)$ dan $4-d_{U}(2,154)$. Hal ini merupakan bukti tidak adanya autokorelasi positif maupun negatif dalam model regresi. Ringkasan hasil uji autokorelasi dapat dilihat pada Tabel 9.

Tabel 9 Ringkasan Hasil Uji Autokorelasi

\begin{tabular}{lcccc}
\hline No & DW hitung & $\begin{array}{c}\text { Nilai } \\
\mathrm{d}_{\mathrm{U}}\end{array}$ & $\begin{array}{c}\text { Nilai } \\
4-\mathrm{d}_{\mathrm{U}}\end{array}$ & Keterangan \\
\hline 1 & 2,025 & 1,846 & 2,154 & Tidak Ada Autokorelasi \\
\hline \multicolumn{2}{l}{ Sumber: data hasil spss }
\end{tabular}

\section{Analisis Regresi Moderasi}

Berdasarkan output analisis regresi moderasi dengan bantuan software SPSS for Windows pada Lampiran, selanjutnya diperoleh hasil perhitungan yang dapat diringkas seperti tertera pada Tabel 10 di bawah ini: 
Tabel 10 Ringkasan Hasil Analisis Regresi Moderasi

\begin{tabular}{clrrrr}
\hline No & \multicolumn{1}{c}{ Variabel } & $\begin{array}{c}\text { Koefisien } \\
\text { Regresi }\end{array}$ & \multicolumn{1}{c}{$\mathrm{t}_{\text {hitung }}$} & & $\begin{array}{c}\mathrm{t}_{\text {tabel }} \\
\text { (satu sisi) }\end{array}$ \\
\hline 1 & NPF $\left(\mathrm{X}_{1}\right)$ & $-0,006$ & $-0,234$ & $>$ & $-1,660$ \\
2 & NOM $\left(\mathrm{X}_{2}\right)$ & 0,101 & 3,541 & $>$ & 1,660 \\
3 & FDR $\left(\mathrm{X}_{3}\right)$ & 0,059 & 3,506 & $>$ & 1,660 \\
4 & DPK $(\mathrm{Z})$ & 0,890 & 22,480 & $>$ & 1,660 \\
5 & Moderasi_1 (X $1 . \mathrm{Z})$ & 0,021 & 0,794 & $>$ & $-1,660$ \\
6 & Moderasi_2 $\left(\mathrm{X}_{2} . \mathrm{Z}\right)$ & 0,070 & 1,932 & $>$ & 1,660 \\
7 & Moderasi_3 $\left(\mathrm{X}_{3} . \mathrm{Z}\right)$ & 0,038 & 2,199 & $>$ & 1,660 \\
\hline
\end{tabular}

$\begin{array}{ll}\text { Konstanta } & =-0,001 \\ \text { R Square } & =0,868 \\ \text { Adj. } \text { R Square } & =0,861 \\ \text { Fhitung } & =111,269\end{array}$

Sumber: data hasil spss

Berdasarkan data pada Tabel 4.8, dapat dibuat persamaan regresi moderasi sebagai berikut:

$$
\begin{aligned}
& \mathrm{Y}=-0,001-0,006 \mathrm{X}_{1}+0,101 \mathrm{X}_{2}+0,059 \mathrm{X}_{3}+0,890 \mathrm{Z}+0,021 \mathrm{MOD} \_1+ \\
& \text { 0,070MOD_2 }+ \text { 0,038MOD_3+e }
\end{aligned}
$$

Uji Goodness of Fit

Hasil Koefisien Determinasi

Ringkasan hasil analisis regresi moderasi pada Tabel 4.8 menunjukkan bahwa koefisien determinasi $\left(\mathrm{R}^{2}\right)$ sebesar 0,868 dengan koefisien adjusted $R$ square sebesar 0,861 . Koefisien tersebut menunjukkan bahwa sebesar 86,10 persen variasi perubahan naik turunnya pembiayaan murabahah pada Bank Umum Syariah di Indonesia dapat dijelaskan oleh variabel Non Performing Financing, Net Operating Margin, Financing to Deposit Ratio, Dana Pihak Ketiga, variabel moderasi_1, moderasi_2 dan variabel moderasi_3, sedangkan 13,90 persen dapat dijelaskan oleh variabel-variabel lain yang tidak diteliti.

Hasil Uji F

Berdasarkan ringkasan hasil analisis regresi moderasi pada Tabel 4.8 juga dapat diketahui nilai $F_{\text {hitung }}$ sebesar 111,269 lebih besar dari nilai $F_{\text {tabel }}$ dengan $\mathrm{df}=\mathrm{n}-(\mathrm{k}+1)$ yaitu 2,09. Hasil uji F tersebut menunjukkan bahwa secara keseluruhan (simultan) variabel Non Performing Financing, Net Operating Margin, Financing to Deposit Ratio, Dana Pihak Ketiga, variabel moderasi_1, moderasi_2 dan variabel moderasi_3 mempunyai pengaruh yang signifikan terhadap pembiayaan murabahah pada Bank Umum Syariah di Indonesia.

\subsection{Pembahasan}

\section{a. Pengaruh Non Performing Financing (NPF) Terhadap Pembiayaan Murabahah}

Hasil penelitian ini menunjukkan bahwa nilai thitung variabel Non Performing Financing $(-0,234)$ lebih besar dari nilai -t tabel $(-1,660)$ sehingga dapat diartikan bahwa Non Performing Financing mempunyai pengaruh yang negatif tetapi tidak signifikan terhadap pembiayaan murabahah pada Bank Umum Syariah di Indonesia. Hubungan kausal tersebut mengindikasikan bahwa semakin tinggi tingkat Non Performing Financing tidak selalu diikuti dengan semakin rendahnya jumlah pembiayaan murabahah pada Bank Umum Syariah di Indonesia. 
$N P F$ yang semakin tinggi, maka resiko pembiayaan yang ditanggung oleh bank juga semakin tinggi. Sebelum bank menyalurkan pembiayaan, bank harus menganalisis lebih lanjut mengenai kemampuan debitur untuk membayar kembali pembiayaan tersebut. Nilai NPF tinggi tidak selalu diikuti dengan semakin rendahnya pembiayaan murabahah, selama bank dapat memastikan kemampuan debitur untuk dapat membayar kembali pembiayaan sebelum bank memutuskan untuk memberikan pembiayaan.

Hasil penelitian ini berbeda dengan temuan studi sebelumnya yang dilakukan oleh Nahrawi (2017) bahwa Non Performing Financing berpengaruh negatif signifikan terhadap pembiayaan murabahah. Penelitian tersebut merupakan studi kasus pada satu bank umum syariah maka dari itu hasil yang diperoleh tidak representatif. Di sisi lain, hasil penelitian ini sejalan dengan temuan studi sebelumnya yang dilakukan oleh Asnaini dan Erawati (2017), Ali dan Mitahurrohman (2017) dan Azka, et.al (2018) bahwa Non Performing Financing (NPF) tidak berpengaruh secara signifikan terhadap pembiayaan murabahah.

\section{b. Pengaruh Net Operating Margin (NOM) Terhadap Pembiayaan Murabahah}

Hasil penelitian ini menunjukan bahwa nilai thitung variabel Net Operating Margin (3,541) lebih besar dari nilai tabel (1,660). Hasil uji tersebut membuktikan bahwa Net Operating Margin (NOM) mempunyai pengaruh yang positif dan signifikan terhadap pembiayaan murabahah. Hubungan kausal tersebut menunjukkan bukti bahwa semakin tinggi tingkat Net Operating Margin (NOM) akan selalu diikuti dengan semakin tingginya jumlah pembiayaan murabahah pada Bank Umum Syariah di Indonesia.

Semakin meningkatnya Net Operating Margin (NOM) maka menandakan bahwa kualitas aset produktif bank tersebut baik. Salah satu aset produktif adalah kredit, apabila kualitas kredit baik maka bank akan memperoleh pendapatan yang optimal dari kredit tersebut. Pendapatan operasional inilah yang akan menghasilkan laba. Melihat kesempatan perolehan laba yang dapat dihasilkan dari kualitas aset yang baik, maka akan membuat bank lebih tertarik untuk menyalurkan pembiayaan murabahah yang lebih besar untuk tahun berikutnya

Hasil penelitian ini sejalan dengan temuan studi sebelumnya yang dilakukan oleh Sari dan Haryanto (2017) bahwa Net Operating Margin (NOM) berpengaruh positif signifikan terhadap profitabilitas, serta penelitian Harahap (2015) dan Munthe (2016) yang menyatakan bahwa Net Interest Margin (NIM) berpengaruh positif signifikan terhadap ROA. Hasil penelitian ini juga didukung dengan temuan studi yang dilakukan oleh Ali dan Miftahurrohman (2016) dan Nahrawi (2017) yang menyimpulkan bahwa profitabilitas berpengaruh positif signifikan terhadap pembiayaan murabahah.

\section{c. Pengaruh Financing to Deposit Ratio (FDR) Terhadap Pembiayaan Murabahah}

Hasil penelitian ini menunjukkan nilai thitung variabel Financing to Deposit Ratio $(3,506)$ juga lebih besar dari nilai tabel $(1,660)$. Hasil uji statistik tersebut menunjukkan bukti bahwa secara parsial variabel Financing to Deposit Ratio (FDR) mempunyai pengaruh yang positif dan signifikan terhadap 
pembiayaan murabahah. Hubungan kausal tersebut memberikan bukti bahwa semakin tinggi Financing to Deposit Ratio, maka akan semakin tinggi pula jumlah pembiayaan murabahah pada Bank Umum Syariah di Indonesia.

Standar nilai FDR yang telah ditetapkan oleh Bank Indonesia adalah 80\%-110\%. Nilai FDR 80-110\% artinya bank telah menjalankan fungsi mediasi atau perantara dengan baik. Apabila nilai FDR suatu bank di bawah $80 \%$ maka bank hanya dapat menyalurkan pembiayaan kurang dari $80 \%$ dari dana yang dapat dihimpun. Dengan nilai tersebut maka bank dinilai tidak dapat menjalankan fungsi utamanya yaitu sebagai lembaga perantara dengan baik, artinya kemampuan bank untuk memediasi antara pihak yang kelebihan dana dengan pihak yang membutuhkan dana itu buruk. Sebaliknya apabila nilai FDR lebih dari $110 \%$ itu berarti bank telah menyalurkan pembiayaan lebih dari dana dapat dihimpun oleh bank. Nilai tersebut masuk ke dalam kategori likuiditas yang buruk, artinya bank akan mengalami kesulitan untuk mengembalikan dana apabila sewaktu-waktu deposan ingin menarik dana yang telah dihimpun pada bank tersebut.

Rata-rata nilai FDR pada bank umum syariah di Indonesia adalah 92,81\% dan angka tersebut masuk ke dalam kategori sehat. Angka rasio FDR yang sehat menunjukan bahwa sebagian besar dana yang dihimpun oleh bank disalurkan kembali kepada masyarakat, sehingga masyarakat akan lebih percaya untuk melakukan pembiayaan. Salah satunya adalah pembiayaan murabahah, sehingga pembiayaan murabahah pun akan meningkat di tahun berikutnya. Hasil penelitian ini sejalan dengan hasil studi sebelumnya yang dilakukan oleh Prastanto (2013) dan Janah (2018) yang membuktikan bahwa FDR berpengaruh positif terhadap pembiayaan murabahah.

\section{d. Pengaruh Non Performing Financing terhadap Pembiayaan Murabahah Melalui Dana Pihak Ketiga (DPK) Sebagai Pemoderasi}

Hasil penelitian ini menunjukkan bahwa nilai thitung variabel moderasi_1 $(0,794)$ lebih besar dari nilai -t tabel $(-1,660)$. Hasil uji tersebut menunjukkan bahwa variabel moderasi_1 mempunyai pengaruh yang positif namun tidak signifikan terhadap pembiayaan murabahah. Hasil yang tidak signifikan ini menunjukan bahwa Dana Pihak Ketiga (DPK) tidak dapat memoderasi pengaruh NPF terhadap pembiayaan murabahah. Hubungan kausal tersebut mengindikasikan bahwa semakin tinggi jumlah Dana Pihak Ketiga tidak selalu diikuti dengan semakin kuatnya pengaruh NPF dalam menurunkan pembiayaan murabahah.

Hal tersebut dapat diartikan bahwa tingginya Dana Pihak Ketiga yang dapat dihimpun bank umum syariah tidak selalu dapat menaikan pembiayaan murabahah ketika nilai NPF tahun sebelumnya besar. Ketika Dana Pihak Ketiga yang dihimpun besar, bank tidak akan langsung meningkatkan pembiayaan murabahah melainkan tetap mempertimbangkan NPF serta kemampuan kreditur dalam pembayaran kembali pembiayaan. Hal ini akan dapat mengurangi resiko pembiayaan bermasalah terjadi kembali.

Hasil penelitian ini sejalan dengan hasil studi sebelumnya dari Harahap (2015) yang menyimpulkan bahwa Dana Pihak Ketiga (DPK) tidak mampu secara signifikan memoderasi pengaruh Non Performing Loan terhadap kinerja keuangan bank. 


\section{e. Pengaruh Net Operating Margin terhadap Pembiayaan Murabahah Melalui Dana Pihak Ketiga (DPK) Sebagai Pemoderasi}

Hasil penelitian ini menunjukkan bahwa nilai thitung variabel moderasi_2 $(1,932)$ lebih besar dari nilai t tabel $(1,660)$. Hasil uji tersebut menunjukkan bukti bahwa variabel moderasi_2 mempunyai pengaruh yang positif dan signifikan terhadap pembiayaan murabahah. Artinya dalam hubungan NOM dengan pembiayaan murabahah variabel Dana Pihak Ketiga dapat dikatakan sebagai variabel moderasi.Hubungan kausal tersebut mengindikasikan bahwa semakin tinggi jumlah Dana Pihak Ketiga akan selalu diikuti dengan semakin kuatnya pengaruh NOM dalam meningkatkan pembiayaan murabahah pada Bank Umum Syariah di Indonesia.

Hal ini dikarenakan dengan semakin besar Dana Pihak Ketiga yang dapat dihimpun bank syariah akan semakin meningkatkan pembiayaan murabahah karena nilai NOM tinggi. Nilai NOM yang tinggi ini akan membuat bank syariah lebih tertarik untuk meningkatkan jumlah pembiayaan murabahah didukung dengan adanya Dana Pihak Ketiga yang merupakan sumber utama penyaluran dana ke masyarakat dalam bentuk pembiayaan.

Hasil penelitian ini sesuai dengan Teori Stewardship yang menjelaskan bahwa principal akan memutuskan untuk bekerja sama dengan steward karena adanya rasa kepercayaan (trust). Principal akan menaruh kepercayaan pada bank dengan menghimpun dananya pada bank dan principal percaya bawah dana tersebut akan dikelola dengan baik oleh bank syariah melalui pembiayaan. Perilaku steward dalam hal ini adalah kolektif dimana bank akan terus mencari cara untuk mencapai tujuan perusahaan yaitu pertumbuhan profitabilitas melalui pendapatan operasional yang dapat diukur oleh NOM. Jadi, bank akan memanfaatkan kepercayaan dari principal berupa Dana Pihak Ketiga yang dihimpun untuk meningkatkan pendapatan sehingga akan berdampak kembali kepada principal berupa pembiayaan yang bank salurkan.

Hasil penelitian ini juga sesuai dengan temuan studi yang dilakukan oleh Munthe (2016) yang membuktikan bahwa Dana Pihak Ketiga (DPK) mampu memoderasi pengaruh Net Interest Margin terhadap kinerja keuangan bank.

\section{f. Pengaruh Financing to Deposit Ratio terhadap Pembiayaan Murabahah Melalui Dana Pihak Ketiga (DPK) Sebagai Pemoderasi}

Hasil penelitian ini menunjukkan bahwa nilai thitung variabel moderasi_3 $(2,199)$ lebih besar dari nilai tabel $(1,660)$. Hasil uji statistik tersebut menunjukkan bukti bahwa variabel moderasi_3 mempunyai pengaruh yang positif dan signifikan terhadap pembiayaan murabahah. Artinya dalam hubungan FDR dengan pembiayaan murabahah variabel Dana Pihak Ketiga dapat dikatakan sebagai variabel moderasi. Hubungan kausal tersebut mengindikasikan bahwa semakin tinggi jumlah Dana Pihak Ketiga akan selalu diikuti dengan semakin kuatnya pengaruh FDR dalam meningkatkan pembiayaan murabahah pada Bank Umum Syariah di Indonesia.

Hal tersebut akan selalu terjadi selama nilai rasio $F D R$ berada dalam standart nilai $F D R$ yang sehat yaitu $80 \%-110 \%$. Hal ini dikarenakan dengan nilai $F D R$ yang tinggi menunjukan bahwa bank telah menjalankan fungsinya sebagai lembaga perantara dengan baik yaitu sebagai lembaga penghubung, untuk menyalurkan dana kepada pihak yang membutuhkan dari pihak yang kelebihan dana. Dengan ini masyarakat akan lebih percaya untuk melakukan 
pembiayaan di bank tersebut. Apabila Dana Pihak Ketiga tinggi maka bank akan memiliki dana yang lebih banyak untuk menyalurkan pembiayaan, sehingga pembiayaan yang disalurkan akan semakin banyak.

Hasil penelitian ini juga sesuai dengan temuan studi yang dilakukan oleh Munthe (2016) yang membuktikan bahwa Dana Pihak Ketiga (DPK) mampu memoderasi pengaruh Loan to Deposit Ratio terhadap kinerja keuangan bank.

\section{PENUTUP}

Hasil penelitian ini menunjukkan bahwa secara simultan, NOM, FDR berpengaruh positif signifikan terhadap besar kecilnya pembiayaan murabahah yang disalurkan oleh Bank Umum Syariah yang ada di Indonesia. Namun, berbeda dengan NPF yang tidak berpengaruh negatif signifikan terhadap pembiayaan murabahah. Dana Pihak Ketga (DPK) dapat memperkuat atau memoderasi pengaruh positif NOM dan FDR terhadap pembiayaan murabahah pada bank umum syariah. Namun, Dana Pihak Ketiga (DPK) tidak memoderasi pengaruh negatif NPF terhadap pembiayaan murabahah pada bank umum syariah.

Penelitian ini dapat digunakan sebagai upaya untuk terus meningkatkan jumlah pembiayaan murabahah. Untuk meningkatkan jumlah pembiayaan murabahah manajerial Bank Umum Syariah di Indonesia perlu memprioritaskan kebijakan yang terkait dengan Net Operating Margin (NOM), Financing to Deposit Ratio (FDR) dan Dana Pihak Ketiga (DPK).

Keterbatasan dalam penelitian ini adalah menggunakan data pada laporan keuangan triwulan bank umum syariah. Untuk penelitian yang akan datang diharapkan dapat menggunakan laporan keuangan bulanan bank umum syariah agar sampel yang diperoleh lebih representatif. 


\section{DAFTAR PUSTAKA}

Ali, Herni dan Miftahurrohman. (2016). Determinan yang Mempengaruhi Pembiayaan Murabahah pada Perbankan Syariah di Indonesia. Jurnal Bisnis dan Manajemen Vol. 6 No. 1.

Asnaini, Sri Wahyuni dan Erawati, Desyi. (2017). Faktor-faktor yang Mempengaruhi Pembiayaan Murabahah pada Bank Umum Syariah di Indonesia. JOCE IP Vol. 11 No.1.

Azka, Widya Karunia., Hardiwinoto., Wibowo, R Ery. (2018). Analisis Faktor-faktor yang Mempengaruhi Pembiayaan Murabahah pada Perbankan Syariah di Indonesia. Prosiding Seminar Nasional Mahasiswa Unimus Vol. 1 e-ISSN: 2654-766X.

Dendawijaya, Lukman. (2005). Manajemen Perbankan. Bogor: Ghalia Indonesia. . (2009). Manajemen Perbankan. Jakarta: Ghalia Indonesia.

Donaldson, L dan Davis, J. (1991). Stewardship Theory or Agency Theory : CEO Governance and Shareholder Return. Australian Journal of Management, Vol. 16 No. 3 pp 49-64.

Gumilarty, Gittrys Ratu Mashita dan Indriani, Astiwi. (2016). Analisis Pengaruh DPK, NPF, ROA, Penempatan Dana pada SBIS, dan Tingkat Bagi Hasil Terhadap Pembiayaan Bagi Hasil. Diponegoro Journal of Management, Vol. 5 No.4. Hal 1-14.

Harahap. (2015). Analisis Pengaruh Net Interest Margin, Beban Operasional terhadap Pendapatan Operasional, Non Performing Loan dan Loan to Deposit Ratio terhadap Kinerja Keuangan Bank Pembangunan Daerah di Indonesia dengan Dana Pihak Ketiga sebagai Variabel Moderating. Skripsi. Diakses di http://repository.usu.ac.id.

Hartono, Jogiyanto. (2017). Metodologi Penelitian Bisnis (Salah Kaprah dan Pengalaman-Pengalaman) Edisi 6. Yogyakarta: BPFE.

Kalsum, Ummi. (2014). Riba dan Bunga Bank dalam Islam. Jurnal Al'Adl Vol 7 No.2.

Muhammad, (2005). Manajemen Bank Syariah. Yogyakarta: UPP AMP YKPN.

Munthe. (2016). Analisis Pengaruh Rasio-Rasio Keuangan terhadap Kinerja Perbankan di Bursa Efek Indonesia dengan Pertumbuhan Dana Pihak Ketiga sebagai Variabel Moderating. Tesis. Universitas Sumatera Utara.

Nahrawi, Amirah Ahmad. (2017). Pengaruh Pengaruh Capital Adequaty Ratio (CAR), Return On Assets (ROA) dan Non Performing Financing (FDR) terhadap Pembiayaan Murabahah BNI Syariah. Jurnal Perisai Vol. 1 No. 2.

Prastanto. (2013). Faktor yang Mempengaruhi Pembiayaan Murabahah pada Bank Umum Syariah di Indonesia. Accounting Analysis Journal Vol. 2 No.1.

Rivai, Veithzal dan Arifin, Arviyan. (2010). Islamic Banking : Sebuah Teori, Konsep, dan Aplikasi. Jakarta: PT Bumi Aksara.

Sari, Silfani Permata., Haryanto, A Mulyo. (2017). Analisis Pengaruh Capital Adequacy Ratio, Net Opearting Margin, Financing to Deposit Ratio, Non Performing Financing dan Pembiayaan Bagi Hasil Terhadap Profitabilitas Bank Umum Syariah di Indonesia. Diponegoro Journal of Management Vol. 6 No. 4 Hal.1-15.

Sudarsono, Heri. (2008). Bank dan Lembaga Keuangan Syariah Deskripsi dan Ilustrasi. Yogyakarta: Ekonisia.

Surat Edaran Bank Indonesia No. 9/24/DPbS perihal Sistem Penilaian Tingkat Kesehatan Bank Umum Berdasarkan Prinsip Syariah. 